\title{
Effect of Growth Regulators and Micronutrients on Fruit Quality in Pomegranate
}

\author{
Kuldip Kumar, M. S. Joon, Rajpaul Yadav, B.S. Daulta
}

Department of Horticulture, CCSHAU, Hisar, Haryana, India

\begin{abstract}
A field experiment was conducted at Fruit Research Farm of Haryana Agricultural University, Hisar to evaluate the effect of micronutrients and plant growth regulators on fruit quality in pomegranate cv. Jodhpur Red. The treatments comprising of two micronutrients $\left(\mathrm{H}_{3} \mathrm{BO}_{3}\right.$ \& $\mathrm{ZnSO}_{4}$ at 0.20, 0.40, $\left.0.60 \%\right)$, two growth regulators (2,4-D \& NAA at 10,20, $40 \mathrm{ppm}$ ) and water were applied fifteen and thirty days after fruit set. Application of 2,4-D at 40 ppm resulted in more total soluble solids. $\mathrm{H}_{3} \mathrm{BO}_{3}$ resulted in more ascorbic acid content when applied at fifteen days after fruit set. 2,4-D when applied at fifteen days after fruit set, significantly increased reducing sugar content. Application of micronutrients and growth regulators applied fifteen days after fruit set was more effective in improving fruit quality as compared to thirty days after fruit set.
\end{abstract}

Keywords- Growth Regulator, Micronutrient, Fruit Quality, Pomegranate.

\section{INTRODUCTION}

Pomegranate (Punica granatum L.) is an important fruit crop of the tropical and subtropical regions of the world. It can be grown from plains to an elevation of up to 2000 meter. Under temperate environment, it behaves as a deciduous plant while in subtropical and tropical climate it behaves as evergreen or partially deciduous plant. In India, it is cultivated in over 1.20 lakh ha area with an annual production of 7.5 lakh tonnes and with a productivity of about 6.60 tonnes per ha. Maharashtra state is the largest producer of this fruit crop in India. The edible part of the fruit is called arils which are eaten fresh and can be preserved as syrup or used for making jam. The fruit peel, stem, root bark and leaves are a good source of secondary products such as tannins, dyes and alkaloids. Anthocyanin in pomegranate arils is a rich source of antioxidants. The edible parts of fruit contain considerable amount of proteins, carbohydrates, minerals, sugars, vitamins, polysaccharides and polyphenols. The reducing sugars, nonreducing sugars, total sugars, acidity, ascorbic acid and total soluble solids etc. are important components determining quality of fruit juice in pomegranate. The quality of the pomegranate fruits is manageable through maintaining soil moisture and avoiding wide variation in soil moisture, cultivation of recommended cultivars and application of adequate and regular irrigation during fruit growth stages. Also, use of growth regulators and micronutrients has also been reported effective in managing fruit quality in pomegranate (Malhotra et al. 1983; Reddy and Prasad, 2012; Venkatesan and Mohideen, 1994). Although several workers have evaluated the effect of nutrients and growth regulators on fruit quality of pomegranate in different parts of the world; the present study was undertaken to complement the available information on this aspect under Haryana conditions.

\section{MATERIALS AND METHODS}

Two set of separate experiments were laid out on six years old cv. Jodhpur Red of pomegranate planted at $5 \times 5 \mathrm{~m}$ spacing with fourteen treatments comprising of two micronutrients $\left(\mathrm{H}_{3} \mathrm{BO}_{3} \& \mathrm{ZnSO}_{4}\right.$ at $\left.0.20,0.40,0.60 \%\right)$, two growth regulators (2,4-D \& NAA at 10, 20, $40 \mathrm{ppm})$, water spray and control under each set. The experimental unit was kept as one plant per treatment with four replications. All the experimental plants were given uniform cultural practices and care as recommended in the package \& practices of Haryana Agricultural University, Hisar. Under two stages of application, first spray of the nutrients, growth regulators and water was given 15 days after fruit set i.e. on $26^{\text {th }}$ May, 1995 (Stage-I); second spray of all the fourteen treatments was given 30 days after fruit set i.e. on 10 June, 1995 (Stage-II). All the chemicals were dissolved in water and desired concentration were freshly prepared and solution was sprayed with hand sprayer on the whole plant covering all the fruits. For recording of data, the fruits of different treatments were harvested at marketable size. Observations on aril weight, rind weight, aril softness (soft, medium, hard), reducing sugar, non-reducing sugar, total sugar, acidity, ascorbic acid and total soluble solids etc. was recorded as per standard procedure. Data recorded on 
various parameters were analyzed by following randomized block design.

\section{RESULTS AND DISCUSSION}

Effect on Aril and Rind Weight: The perusal of data in table-I indicated that all treatments significantly increased aril weight (excepting $\mathrm{ZnSO}_{4}$ at $0.6 \%(95.00 \mathrm{~g}), \mathrm{H}_{3} \mathrm{BO}_{3}$ at $0.2 \%$ (95.00 g) and $\mathrm{H}_{3} \mathrm{BO}_{3}$ at $0.6 \%$ (100.25 g) over control $(91.88 \mathrm{~g})$ at stage-I. The maximum increase in aril weight at stage-I was recorded with NAA at $20 \mathrm{ppm}$ and 2,4-D at 10 ppm $(135.00 \mathrm{~g})$ each followed by $\mathrm{ZnSO}_{4}$ at $0.2 \%$ (122.50 g), 2,4-D at $40 \mathrm{ppm}(120.62 \mathrm{~g}), \mathrm{ZnSO}_{4}$ at $0.4 \%(15.00 \mathrm{~g})$, $\mathrm{NAA}$ at $40 \mathrm{ppm}(114.37 \mathrm{~g}), 2,4-\mathrm{D}$ at $20 \mathrm{ppm}(110.92 \mathrm{~g})$, $\mathrm{H}_{3} \mathrm{BO}_{3}$ at $0.4 \%(109.37 \mathrm{~g}), \mathrm{NAA}$ at $10 \mathrm{ppm}(108.12 \mathrm{~g})$ and $\mathrm{H}_{3} \mathrm{BO}_{3}$ at $0.6 \%$ (100.25 g) as compared to control (91.88 g). At stage-II, 2,4-D at $10 \mathrm{ppm}(196.25 \mathrm{~g})$ resulted in maximum aril weight followed by 2,4-D at $40 \mathrm{ppm}$ (138.75 g), NAA at $20 \mathrm{ppm}(177.87 \mathrm{~g})$, NAA at $40 \mathrm{ppm}(108.12 \mathrm{~g})$, $\mathrm{H}_{3} \mathrm{BO}_{3}$ at $0.6 \%$ (103.12 g), 2,4-D at $20 \mathrm{ppm}(103.19 \mathrm{~g})$ and $\mathrm{H}_{3} \mathrm{BO}_{3}$ at $0.4 \%(101.87 \mathrm{~g})$ over control $(91.25 \mathrm{~g})$. Mean aril weight was more at stage-II in comparison with stage-I of application of micronutrients and growth regulators (TableI). It was also evident from the present studies that rind weight increased in most of the treatments of micronutrients irrespective of the stage. The ratio of aril weight (AW) and rind weight $(\mathrm{RW})$ was not increased significantly by any of the treatments excepting $\mathrm{ZnSO}_{4} 0.2 \%$ (1.72) at stage-I and water spray (1.94) at stage-II. The lowest $\mathrm{AW} / \mathrm{RW}$ ratio (1.24) was recorded with application of $\mathrm{ZnSO}_{4}$ at $0.6 \%$ at stage-I; whereas at stage-II, minimum AW/RW ratio (1.24) was recorded with $\mathrm{H}_{3} \mathrm{BO}_{3}$ at $0.4 \%$. The results are in agreement with those of Rahemi and Atahosseini (2004) who obtained improved aril and rind weight with application of 2,4-D at $30 \mathrm{ppm}$ and NAA at $50 \mathrm{ppm}$ in pomegranate. Reddy and Prasad (2012) also reported that pomegranate trees applied with $40 \mathrm{ppm} 2,4-\mathrm{D}$ and $75 \mathrm{ppm}$ GA resulted in better aril development and yield.

Effect on Sugar Content: There was no significant difference in non- reducing sugars at stage-II as a result of application of various growth regulators and micronutrients in all treatments as compared to control $(0.74 \%)$. 2,4-D at $40 \mathrm{ppm}$ and $10 \mathrm{ppm}$ recorded maximum reducing sugar content during stage-I and stage-II, respectively. However, at stage-I, $\mathrm{H}_{3} \mathrm{BO}_{3}$ at $0.2 \%$ and 2,4-D at $10 \mathrm{ppm}$ recorded maximum reducing-sugar $(0.91 \%)$ followed by $\mathrm{H}_{3} \mathrm{BO}_{3}$ at $0.4 \%(0.90 \%), 2,4-\mathrm{D}$ at $20 \mathrm{ppm}(0.85 \%)$ and $2,4-\mathrm{D}$ at 40 ppm $(0.80 \%)$. The control treatment recorded a non reducing-sugar content of $0.76 \%$ (Table-I). At stage-I, all the treatments significantly increased total sugars. Highest total sugar was observed in $2,4-\mathrm{D}$ at $40 \mathrm{ppm}(10.78 \%)$ followed by 2,4-D at $10 \mathrm{ppm}$ (10.57\%), 2,4-D at $20 \mathrm{ppm}$ $(10.55 \%), \mathrm{ZnSO}_{4}$ at $0.4 \%(10.40 \%), \mathrm{NAA}$ at $20 \mathrm{ppm}$ $(10.40 \%), \mathrm{NAA}$ at $40 \mathrm{ppm}(10.36 \%), \mathrm{ZnSO}_{4}$ at $0.6 \%$ $(10.35 \%), \mathrm{ZnSO}_{4}$ at $0.2 \%(10.33 \%)$ and $\mathrm{NAA}$ at $10 \mathrm{ppm}$ $(10.27 \%)$. At stage-II, application of 2,4-D at $40 \mathrm{ppm}$ (10.91\%) followed by $2,4-\mathrm{D}$ at $10 \mathrm{ppm}(10.78 \%)$ recorded highest values for total sugar.

Effect on Aril Softness: The treatments comprising $\mathrm{ZnSO}_{4}$ at $0.4 \%, \mathrm{ZnSO}_{4}$ at $0.6 \%, \mathrm{H}_{3} \mathrm{BO}_{3}$ at $0.4 \%, \mathrm{H}_{3} \mathrm{BO}_{3}$ 0.at $6 \%$, 2,4-D at $10 \mathrm{ppm}$ and 2,4-D at $40 \mathrm{ppm}$ recorded softness of seed at stage-I (Table-2). At stage-II, $\mathrm{ZnSO}_{4}$ at $0.6 \%$ $\mathrm{H}_{3} \mathrm{BO}_{3}$ at $0.4 \%, \mathrm{H}_{3} \mathrm{BO}_{3}$ at $0.6 \%$, NAA at $10 \mathrm{ppm}$, NAA at $40 \mathrm{ppm}$ and 2,4-D at $40 \mathrm{ppm}$ recorded softness of the seed in fruit. Water spray also resulted in softness of the seed as compared to treatment without water spray at stage-II.

Effect on TSS and Ascorbic Acid: There was no significant increase in T.S.S. content among different treatments [excepting 2,4-D at $40 \mathrm{ppm}$ (13.90\%)] over control $(13.00 \%)$ when the treatments were applied 15 days after fruit set. When treatments were applied 30 days after fruit set, there was no significant increase in T.S.S. except with 2,4-D at $40 \mathrm{ppm}(14.00 \%)$ over control (13.30\%). More T.S.S. (13.42) was recorded at the stage-II as compared to stage-I (13.15). Results indicated that all the three concentration of $\mathrm{H}_{3} \mathrm{BO}_{3}, \mathrm{ZnSO}_{4}$ at $0.4 \%(24.03 \mathrm{mg}$ ), $\mathrm{NAA}$ at $10 \mathrm{ppm}(22.65 \mathrm{mg}), \mathrm{NAA}$ at $40 \mathrm{ppm}(23.06 \mathrm{mg})$ and 2,4-D at $10 \mathrm{ppm}(24.00 \mathrm{mg})$ significantly increased the ascorbic acid over control at stage-I. All the treatments significantly increased the ascorbic acid content at stage-I excepting $\mathrm{H}_{3} \mathrm{BO}_{3}$ at $0.6 \%(20.07 \mathrm{mg})$, NAA at $10 \mathrm{ppm}$ $(19.99 \mathrm{mg})$ and $2,4-\mathrm{D}$ at $40 \mathrm{ppm}(20.59 \mathrm{mg})$ over control $(19.55 \mathrm{mg})$. There was no significant decrease in acidity excepting $\mathrm{ZnSO}_{4}$ at $0.2 \%(0.48 \%), 2,4-\mathrm{D}$ at $10 \mathrm{ppm}$ $(0.47 \%)$ and NAA at $20 \mathrm{ppm}(0.44 \%)$ at stage-I and II, respectively. Maximum acidity was recorded with application of $\mathrm{H}_{3} \mathrm{BO}_{3}$ at $0.2 \%(0.64 \%)$ and $0.6 \%(0.75 \%)$ at stage-I and II, respectively. The mean acidity was same during both the stages of application (Table-2).

Effect on TSS:Acid Ratio : At stage-I, application of $\mathrm{ZnSO}_{4}$ at $0.2 \%$ (27.39) and 2,4-D at $40 \mathrm{ppm}$ (29.57) significantly increased the TSS:Acid ratio over control. At stage-II, application of NAA at $20 \mathrm{ppm}$ (30.22) followed by $\mathrm{H}_{3} \mathrm{BO}_{3}$ at $0.2 \%$ (27.62), 2,4-D at $20 \mathrm{ppm}$ (27.60), $\mathrm{ZnSO}_{4}$ at $0.6 \%$ (27.00), NAA at $40 \mathrm{ppm}(26.66), \mathrm{H}_{3} \mathrm{BO}_{3}$ at $0.4 \%$ (26.60), NAA at $10 \mathrm{ppm}$ (26.27) and 2,4-D at $40 \mathrm{ppm}$ (25.45) recorded more TSS:Acid ratio as compared to control (22.54). Stage-II recorded more TSS:Acid ratio (24.97) than stage-I (24.08). 
The positive effect of auxins (NAA, 2,4-D) on quality parameters could be attributed to enhanced cell division, cell elongation and membrane permeability (Choudhary et al. 2006). Auxins also induce sugar and mineral accumulation at the site of application. The results are in agreement with those of El-Khwaga (2003), who reported more TSS content with use of paclobutrazol in pomegranate. Goswami (2013) also obtained higher TSS, reducing sugar, non reducing sugars and total sugars with application of ethrel at $200 \mathrm{ppm}$ in pomegranate cv. Sinduri. Boron through its role in cell wall synthesis, water uptake in plants; and zinc by activation of enzymes, strengthening of cell wall and cell division play an important role on yield and quality of fruits. The results obtained in this study are in conformity with those of Singh et al. (1990), Zhang and Whiting (2011) and Khalil \& Aly (2013) who reported that adequate quantities of boron and zinc help in obtaining better quality fruits in pomegranate.

\section{CONCLUSION}

Application of 2,4-D at $40 \mathrm{ppm}$ resulted in more total soluble solids during both the stages of application. $\mathrm{H}_{3} \mathrm{BO}_{3}$ resulted in more ascorbic acid content when applied at fifteen days after fruit set. 2,4-D when applied at fifteen days after fruit set, significantly increased reducing sugar content. It is concluded that micronutrients and growth regulators may be applied fifteen days after fruit set for obtaining better quality fruits in pomegranate cv. Jodhpur Red under Haryana conditions.

\section{REFERENCES}

[1] Chaudhary, B.R., Sharma, M.D., Shakya, S.M. and Gautam, D.M. (2006). Effect of plant growth regulators on growth, yield and quality of chilly (Capsicum annuum L.). Journal of the Institute of Agriculture and Animal Science. 27: 65-68.

[2] El-Khawaga, A.S. (2003). Effect of paclobutrazol and zinc sulphate on splitting and fruit quality of
Manfalouty pomegranate trees under upper Egypt conditions. J. Agric. Sci. Mansoura University. 28(8): 6289-6294.

[3] Goswami, J.D.; Patel, N.M.; Bhadauria, H.S. and Wankhade, V.R. (2013) Effect of plant growth regulators on quality traits of pomegranate $\mathrm{cv}$. Sindur. The Asian Journal of Horticulture. 8(1): 361-363

[4] Khalil, H.A. and Aly, S.H.S. (2013). Cracking and fruit quality of pomegranate as affected by pre-harvest spray of some growth regulators and mineral nutrients. Journal of Horticultural Science and Ornamental Plants. 5 (2): 71-76.

[5] Malhotra, H.K.; Khajuria, H.H. and Jawanda, J.S. (1983). Studies on physico-chemical characteristics of pomegranate cultivars. Punjab Horiculture Jourrnal. 23: $153-161$

[6] Rahemi, M. and Atahosseini, A. (2004). Effect of plant growth regulators on fruit characteristics and leaf area of pomegranate cv. Shisheh Cup. Acta Horticulturae. 662: 313-318

[7] Reddy, P. and Prasad, D.M. (2012). Effect of plant growth regulators on fruit characters and yield of pomegranate (Punica granatum L.) cv. Ganesh. International Journal of Plant, Animal and Environmental Sciences. 2(2): 91-93.

[8] Singh, R.P., Sharma, Y.P. and Awasthi, R.P. (1990). Influence of different cultural practices on premature fruit cracking of pomegranate. Progressive Horticulture. 22(1-4): 92-96.

[9] Venkatesan, K. and Mohideen, M.K. (1994). Effect of growth regulators on fruit characters and yield of pomegranate (Punica granatum L.) cv. Ganesh. South Indian Horticulture. 42 (4): 239-244.

[10]Zhang, C. and Whiting, M.D. (2011). Improving 'Bing'sweet cherry fruit quality with plant growth regulators. Scientia Horticulturae. 127: 341-346.

Table.1: Effect of micronutrients and growth regulators on aril weight, rind weight and sugar content in pomegranate cv. Jodhpur Red

\begin{tabular}{|c|c|c|c|c|c|c|c|c|c|c|c|c|c|c|}
\hline \multirow[t]{2}{*}{$\begin{array}{l}\text { Sr. } \\
\text { No. }\end{array}$} & \multirow[t]{2}{*}{ Treatments } & \multirow[t]{2}{*}{ Dose } & \multicolumn{2}{|c|}{ Aril weight } & \multicolumn{2}{|c|}{ Rind Weight } & \multicolumn{2}{|c|}{$\begin{array}{l}\text { AW:RW } \\
\text { Ratio }\end{array}$} & \multicolumn{2}{|c|}{$\begin{array}{l}\text { Reducing } \\
\text { Sugar (\%) }\end{array}$} & \multicolumn{2}{|c|}{$\begin{array}{l}\text { Non reducing } \\
\text { Sugar }(\%)\end{array}$} & \multicolumn{2}{|c|}{$\begin{array}{l}\text { Total Sugar } \\
(\%)\end{array}$} \\
\hline & & & $\begin{array}{l}\text { Stage- } \\
\text { I }\end{array}$ & $\begin{array}{l}\text { Stage- } \\
\text { II } \\
\end{array}$ & $\begin{array}{l}\text { Stage- } \\
\text { I }\end{array}$ & $\begin{array}{l}\text { Stage- } \\
\text { II }\end{array}$ & $\begin{array}{l}\text { Stage- } \\
\text { I }\end{array}$ & $\begin{array}{l}\text { Stage- } \\
\text { II }\end{array}$ & $\begin{array}{l}\text { Stage- } \\
\text { I }\end{array}$ & $\begin{array}{l}\text { Stage- } \\
\text { II }\end{array}$ & $\begin{array}{l}\text { Stage- } \\
\text { I }\end{array}$ & $\begin{array}{l}\text { Stage- } \\
\text { II }\end{array}$ & $\begin{array}{l}\text { Stage- } \\
\text { I }\end{array}$ & $\begin{array}{l}\text { Stage- } \\
\text { II }\end{array}$ \\
\hline 1 & $\mathrm{ZnSO}_{4}$ & $0.2 \%$ & 122.50 & 95.75 & 71.25 & 75.09 & 1.72 & 1.31 & 9.54 & 9.66 & 0.79 & 0.75 & 10.33 & 10.41 \\
\hline 2 & $\mathrm{ZnSO}_{4}$ & $0.4 \%$ & 115.00 & 95.00 & 72.50 & 68.75 & 1.58 & 1.42 & 9.73 & 9.87 & 0.67 & 0.80 & 10.40 & 10.67 \\
\hline 3 & $\mathrm{ZnSO}_{4}$ & $0.6 \%$ & 95.00 & 96.87 & 78.87 & 68.75 & 1.24 & 1.43 & 9.61 & 9.71 & 0.74 & 0.81 & 10.35 & 10.52 \\
\hline
\end{tabular}




\begin{tabular}{|l|l|l|r|l|l|l|l|l|l|l|l|l|l|l|}
\hline 4 & $\mathrm{H}_{3} \mathrm{BO}_{3}$ & $0.2 \%$ & 95.00 & 94.37 & 68.12 & 70.62 & 1.39 & 1.36 & 9.18 & 9.27 & 0.91 & 0.86 & 10.09 & 10.13 \\
\hline 5 & $\mathrm{H}_{3} \mathrm{BO}_{3}$ & $0.4 \%$ & 109.37 & 101.87 & 59.37 & 83.12 & 1.67 & 1.24 & 9.21 & 9.31 & 0.90 & 0.70 & 10.11 & 10.14 \\
\hline 6 & $\mathrm{H}_{3} \mathrm{BO}_{3}$ & $0.6 \%$ & 100.25 & 103.12 & 62.27 & 76.25 & 1.68 & 1.36 & 9.50 & 9.57 & 0.69 & 0.69 & 10.19 & 10.26 \\
\hline 7 & NAA & $10 \mathrm{ppm}$ & 108.12 & 93.12 & 84.37 & 70.00 & 1.39 & 1.34 & 9.53 & 9.66 & 0.74 & 0.79 & 10.27 & 10.46 \\
\hline 8 & NAA & $20 \mathrm{ppm}$ & 135.00 & 117.87 & 80.87 & 81.87 & 1.66 & 1.49 & 9.61 & 9.73 & 0.69 & 0.76 & 10.40 & 10.49 \\
\hline 9 & NAA & $40 \mathrm{ppm}$ & 114.37 & 108.12 & 76.25 & 64.75 & 1.57 & 1.66 & 9.65 & 9.77 & 0.71 & 0.78 & 10.36 & 10.54 \\
\hline 10 & $2,4-\mathrm{D}$ & $10 \mathrm{ppm}$ & 135.00 & 196.25 & 85.00 & 78.75 & 1.53 & 1.57 & 9.76 & 9.90 & 0.91 & 0.61 & 10.57 & 10.78 \\
\hline 11 & $2,4-\mathrm{D}$ & $20 \mathrm{ppm}$ & 110.92 & 103.12 & 70.95 & 61.25 & 1.56 & 1.66 & 9.70 & 9.80 & 0.85 & 0.60 & 10.55 & 10.65 \\
\hline 12 & $2,4-\mathrm{D}$ & $40 \mathrm{ppm}$ & 120.62 & 138.75 & 74.37 & 86.25 & 1.58 & 1.62 & 9.98 & 9.04 & 0.80 & 0.86 & 10.78 & 10.91 \\
\hline 13 & Water & -- & 106.87 & 146.87 & 73.37 & 75.62 & 1.46 & 1.94 & 9.27 & 9.21 & 0.75 & 0.83 & 10.02 & 10.24 \\
\hline 14 & Control & -- & 91.88 & 91.25 & 68.12 & 67.50 & 1.35 & 1.35 & 9.55 & 9.65 & 0.76 & 0.74 & 8.70 & 10.44 \\
\hline 15 & Mean & -- & 98.76 & 152.72 & 78.63 & 80.71 & 1.52 & 1.48 & 9.55 & 9.58 & 0.77 & 0.75 & 10.22 & 10.47 \\
\hline 16 & C.D. at 5\% & -- & 9.39 & 5.85 & 5.61 & 5.09 & 0.36 & 0.38 & 0.17 & 0.34 & 0.19 & NS & 0.14 & 0.43 \\
\hline
\end{tabular}

Table.2: Effect of micronutrients and growth regulators on aril softness, ascorbic acid and TSS in pomegranate cv. Jodhpur Red

\begin{tabular}{|c|c|c|c|c|c|c|c|c|c|c|c|c|}
\hline \multirow[t]{2}{*}{ Sr. No. } & \multirow[t]{2}{*}{ Treatments } & \multirow[t]{2}{*}{ Dose } & \multicolumn{2}{|l|}{ Softness } & \multicolumn{2}{|c|}{ Ascorbic acid } & \multicolumn{2}{|l|}{ TSS } & \multicolumn{2}{|l|}{ Acidity } & \multicolumn{2}{|c|}{$\begin{array}{l}\text { TSS :Acid } \\
\text { Ratio }\end{array}$} \\
\hline & & & Stage-I & Stage-II & $\begin{array}{l}\text { Stage- } \\
\text { I }\end{array}$ & $\begin{array}{l}\text { Stage- } \\
\text { II }\end{array}$ & $\begin{array}{l}\text { Stage- } \\
\text { I }\end{array}$ & $\begin{array}{l}\text { Stage- } \\
\text { II }\end{array}$ & $\begin{array}{l}\text { Stage- } \\
\text { I }\end{array}$ & $\begin{array}{l}\text { Stage- } \\
\text { II }\end{array}$ & $\begin{array}{l}\text { Stage- } \\
\text { I }\end{array}$ & $\begin{array}{l}\text { Stage- } \\
\text { II }\end{array}$ \\
\hline 1 & $\mathrm{ZnSO}_{4}$ & $0.2 \%$ & Medium & Hard & 18.79 & 24.61 & 13.15 & 13.30 & 0.48 & 0.58 & 27.39 & 22.93 \\
\hline 2 & $\mathrm{ZnSO}_{4}$ & $0.4 \%$ & Soft & Medium & 24.03 & 22.96 & 13.40 & 13.50 & 0.50 & 0.56 & 26.80 & 24.10 \\
\hline 3 & $\mathrm{ZnSO}_{4}$ & $0.6 \%$ & Soft & Soft & 19.31 & 24.11 & 13.20 & 13.50 & 0.60 & 0.50 & 22.00 & 27.00 \\
\hline 4 & $\mathrm{H}_{3} \mathrm{BO}_{3}$ & $0.2 \%$ & Medium & Hard & 24.56 & 22.88 & 12.19 & 13.00 & 0.64 & 0.47 & 19.04 & 27.62 \\
\hline 5 & $\mathrm{H}_{3} \mathrm{BO}_{3}$ & $0.4 \%$ & Soft & Soft & 23.96 & 22.67 & 12.80 & 13.30 & 0.50 & 0.50 & 25.60 & 26.60 \\
\hline 6 & $\mathrm{H}_{3} \mathrm{BO}_{3}$ & $0.6 \%$ & Soft & Soft & 21.85 & 20.07 & 13.00 & 13.30 & 0.55 & 0.75 & 23.63 & 17.63 \\
\hline 7 & NAA & $10 \mathrm{ppm}$ & Medium & Soft & 22.65 & 19.99 & 13.20 & 13.40 & 0.54 & 0.51 & 24.44 & 26.27 \\
\hline 8 & NAA & $20 \mathrm{ppm}$ & Medium & Medium & 18.01 & 23.04 & 13.20 & 13.30 & 0.53 & 0.44 & 24.90 & 30.22 \\
\hline 9 & NAA & $40 \mathrm{ppm}$ & Medium & Soft & 23.06 & 22.91 & 13.40 & 13.60 & 0.57 & 0.51 & 23.50 & 26.66 \\
\hline 10 & $2,4-\mathrm{D}$ & $10 \mathrm{ppm}$ & Soft & Medium & 24.00 & 24.57 & 13.70 & 13.70 & 0.60 & 0.55 & 22.83 & 24.90 \\
\hline 11 & $2,4-\mathrm{D}$ & $20 \mathrm{ppm}$ & Hard & $\begin{array}{ll}\text { Hard } \\
\end{array}$ & 19.97 & 22.65 & 13.40 & 13.80 & 0.54 & 0.50 & 24.81 & 27.60 \\
\hline 12 & $2,4-\mathrm{D}$ & $40 \mathrm{ppm}$ & Soft & Soft & 20.95 & 20.59 & 13.90 & 14.00 & 0.47 & 0.55 & 29.57 & 25.45 \\
\hline 13 & Water & -- & Medium & Soft & 20.22 & 20.22 & 12.80 & 13.00 & 0.59 & 0.65 & 21.69 & 20.00 \\
\hline 14 & Control & -- & Medium & Hard & 18.43 & 19.55 & 13.00 & 13.30 & 0.62 & 0.59 & 20.96 & 22.54 \\
\hline 15 & Mean & -- & & & 21.43 & 22.20 & 13.15 & 13.42 & 0.55 & 0.55 & 24.08 & 24.97 \\
\hline 16 & C.D. at $5 \%$ & -- & & & 3.19 & 2.90 & 0.83 & 0.60 & 0.12 & 0.13 & 2.39 & 2.53 \\
\hline
\end{tabular}

